\section{Correlates and Barriers of Dual-Method Contraception among College Youths in Nigeria}

\section{Abstract}

Background and purpose: The dual problems of unintended pregnancies and sexually transmitted infections/Human Immunodeficiency virus together represent one of the most significant public health challenges globally, particularly amongst youths in Sub-Saharan Africa. Although the simultaneous use of two contraceptives, dual method contraception (DMC), is highly effective in preventing these problems, our understanding of the use of DMC is limited in developing country contexts. Thus, this study sets out to assess the correlates and barriers of DMC use amongst youths in Nigeria.

Methods: Data were collected using self-completed questionnaires from 412 undergraduate students selected randomly via multi-stage cluster sampling from three universities. Bivariate chi-square $\left(\chi^{2}\right)$ and multivariate logistic regression analyses were performed to identify variables that were significantly associated use of DMC at the last sexual intercourse.

Results: The prevalence of DMC at last sex was found to be 20.6. However, only $5.4 \%$ of respondents were consistent DMC users. When compared with non-users, DMC users were twice or more likely to: report their age of first sex at or above 16; have had more than one partner in the past year; be currently not seeking pregnancy; have had previous unintended pregnancies; and report having supportive social networks and normative expectations. However, during multivariate analysis, only older age at first sex (AOR=3.081; 95\% Cl: 1.053-9.013; $\mathrm{p}=0.040$ ) and intentions to avoid pregnancy ( $\mathrm{AOR}=2.929 ; 95 \% \mathrm{Cl}: 1.035-8.292$; $\mathrm{p}=0.043$ ) remained significant. Barriers to $\mathrm{DMC}$ use reported by respondents were: difficulty in accessing contraceptives $\chi^{2}(1, N=246)=5.600, p=0.018$; and limited/infrequent counseling on contraception during visits to health facilities $\chi^{2}(1, N=246)=3.941, p=0.047$.

Conclusion: These findings indicate that the practice of DMC is uncommon amongst Nigerian youths. The results call for a multi-level approach that seeks to streamline reproductive health counseling into routine health services delivery.

Keywords: Safer sex; Dual protection; Dual method contraception; Youths; Nigeria
Oto Buraimo', Padam Simkhada ${ }^{2}$, Penny Watson ${ }^{2}$ and Henock B Taddese ${ }^{2}$

1 Vedic Lifecare Hospital Lekki, Lagos State, Nigeria

2 School of Health and Related Research, University of Sheffield, Sheffield, UK

\section{Corresponding author: Oto Buraimo}

” oto.buraimo@gmail.com

Medical Officer, Vedic Lifecare Hospital Lekki, Lagos State, Nigeria.

Tel: +2348033471892

Citation: Buraimo O, Simkhada P, Penny Watson P, et al. Correlates and Barriers of Dual-Method Contraception among College Youths in Nigeria. J Contracept Stud. 2017, $2: 2$

Received: April 21, 2017, Accepted: April 28, 2017 Published: May 04, 2017

\section{Introduction}

The dual problems of unintended pregnancy and sexually transmitted infections/human immunodeficiency virus (STIs/ HIV) together represent one of the most significant, yet largely preventable public health challenges, globally [1]. For instance, in 2008 alone, there were over 498 million new cases of curable STIs, mainly, Gonorrhoea, Syphilis, Chlamydia and Trichomoniasis, among men and women aged 15-49 years [2]; in 2012, around
2.5 million people were newly infected with HIV [3]; and every year, there are about 80 million unintended pregnancies, with about half of these leading to clandestine, unsafe abortions [4]. The combined effect of unintended pregnancies and STIS/ HIV includes debilitating morbidities, untimely deaths as well as multifaceted socio-economic impacts $[5,6]$. These problems are most prevalent amongst adolescents and young people $[7,8]$, especially those residing in Sub-Saharan Africa (SSA) and other resource-poor parts of the world $[3,8]$. 
Nigeria, the most populous SSA country with a young population (median age of 18.5 years) [9], is highly affected. In a country with a high fertility rate of 5.4 offspring per woman [9], an estimated 760,000 unintended pregnancies are also aborted annually $[10,11]$. These figures are bound to be conservative estimates owing to restrictive national abortion laws in the country [12]. Nigeria also harbours the third highest global burden of HIV, after India and South Africa, whereby it is home to around 3.4 million PLHIV (prevalence rate of $3.7 \%$ ) $[13,14]$. The prevalence of other STIs varies between $14 \%$ and $41 \%$ among different population groups, whereby the commonest STIs include: candidiasis, gonorrhoea, and trichomoniasis [15-17].

While low contraceptive prevalence, widespread poverty, low literacy levels and other socio-economic factors are understood to be the deep, underlying causes of unintended conceptions and STIs/HIV amongst Nigerian youths $[18,19]$, the immediate cause for both conditions is attributed to unsafe sexual practices [20]. Thus, efforts by both local and international bodies have been directed at dual protection (DP), which involves safer sexual practices that offer simultaneous prevention of both unintended pregnancies and STIs/HIV [21-23]. Despite the many forms of $D P$, their practice and effectiveness are variable. For example, complete abstinence is the most effective DP practice; however, 'not many [youths] are willing to stop having sex altogether' [24]. Moreover, uninfected infertile couples engaging in unprotected sex in a monogamous relationship would constitute DP; but this is unlikely for many youths as these age-groups have high fecundity, form fragile relationships, and often engage in casual sex $[25,26]$. DP can also be achieved through effective contraception using a barrier method, such as, correct and consistent use of male/ female condoms [27-30]; however, condom-only are associated with high pregnancy rate because of imperfect use [31,32].

In contrast to the above, a 'dual method contraception (DMC)' would effectively tackle STIS/HIV and unwanted conceptions as it involves the simultaneous use of a barrier method to prevent STIs/HIV (such as condoms) and another highly-effective method to prevent conception (such as oral contraceptive pills) [33]. This is the core focus of this study. DMC is also called 'double contraception' [34], 'double Dutch' [35] and 'two methods use' [27]. It commonly involves the use of a male method (usually male condom) with a non-barrier female method such as oral pills (OCPs); emergency contraception (ECPs); female sterilisation; and long-acting contraceptives (LARCs) like injectable, implants, and intra-uterine devices (IUD) [36]. Similarly, DMC can also involve male sterilisation combined with female condom.

Available evidence in the form of population estimates and mathematical modelling have shown the superior infection prevention and anti-conception effects of DMC compared to condom only methods [27,37]. However, numerous challenges are also reported in relation to the practical adoption of DMC by users. The first is that dual-method contraceptives also subject the user to the drawbacks of both condoms and the non-barrier methods used [37]. Second, an inverse relationship has been widely observed with two-method use: individuals initiating/ continuing LARCs in the presence of condoms have often been found to abandon condoms altogether [36,38,39]. Furthermore, two methods use is also associated with increased cost, although it would prove highly cost-effective in the long run [22]. Finally, some authors have also claimed that it may be impracticable to use dual method at every sexual encounter [40].

Studies have reported a low prevalence of use of DMC; ranging from $3 \%$ to $31 \%$ across regions, age-groups, settings, year of study, and dual-method definitions adopted in the studies $[30,41,42]$. In this line, DMC practice is known to be commoner in the developed world and amongst high-risk groups. In addition, individuals are known to be more likely to use DMC if they were younger $[43,44]$; educated $[45,46]$; perceived themselves at risk of STIs/pregnancies $[39,47]$; or perceived themselves to be selfefficacious in terms of using the methods $[48,49]$. Also, individuals who had relationships of recent onset or short duration $[47,50]$, those who communicate with their partners about contraception $[51,52]$, and those who had multiple partners $[53,54]$ were more likely to combine methods.

However, the existing body of literature on DMC pales in comparison to the vast literature on other aspects of reproductive health, and most of the studies are based in North America and Europe. Moreover, DMC studies are fraught with gaps like exclusion of male participants [47], enrolment of non-random samples [55], ambiguous definitions of dual-method [56], and outcome measures that reported only the last-sexual encounter [50]. Thus, we sought to add to the meagre body of literature in this area by seeking to understand the context-specific practice of DMC among male and female youths in Nigeria as well as determining the multi-level predictors of, and barriers to their use.

\section{Method}

\section{Study setting}

This study was conducted at three universities in different regions of Osun, a sub-urban south-western Nigerian State. These were: Obafemi Awolowo University, in Ife, Nigeria (OAU), which is a large public institution, and two small-sized private universities, namely, Oduduwa University Ipetumodu (OUI) and Foreign Links Campus, Moro (FCM) [57-59]. OAU has over 10,000 undergraduate and postgraduate students in over 20 faculties and colleges, whereas FCM and OUI have about 2,000 and 3,500 undergraduate level students respectively, in fewer than ten faculties each. The institutions' student body comprise diverse groups of Nigerian students from all parts of the country as well as international students.

\section{Sample and procedures}

A cross-sectional survey was conducted amongst the youths of these institutions to assess their DMC practices. The sample size was calculated using appropriate survey formulae $[60,61]$. The sampling frame consisted of all the nine universities in Osun and all the faculties in each selected university. We used a multi-stage cluster sampling method [62]. The three-stages were: random selection of a primary sampling unit of three universities from the sampling frame (the nine Universities in the State); random 
selection of three faculties within the selected universities; and finally, selection of 412 undergraduate level students from each selected faculty, through simple random sampling. Youths were eligible if they were Nigerians aged 18 years or above, and if they were currently enrolled in undergraduate programmes at the institutions.

Hand-delivered self-completion questionnaires were employed for data collection. The construction of the variables consulted ecological models $[63,64]$, standardised sexuality-related measures [65], as well as previous DMC studies [47,51-53,55]. Questions were worded in English, the Nigerian lingua franca, to reflect the local socio-cultural context while also ensuring gender neutrality. Comprehension and readability were assessed using the Fog Index (FOG) [66], and a 7.8 FOG score (normal=7-9) was obtained, indicating readability for individuals with higher or equivalent to seven year education. Subsequently, the standardised questionnaire was piloted amongst twenty youths in an unselected university in the area and appropriately amended thereafter. The final questionnaire assessed demographics, psychosocial characteristics, sexual behaviours, and contraceptive practices.

Four local recruiters (two males and two females) approached eligible students in their institutions' premises, during their lunch breaks and after lectures. Recruiters approached students of their own respective gender so as to lessen social desirability reporting bias. All participants were provided with verbal instructions, information sheets, and consent forms to ensure informed consents. Thereafter, consenting respondents were given the self-completion questionnaires, which they filled out while the recruiters waited in the vicinity to clarify in case of any questions while efforts were also made to ensure participants' privacy, confidentiality and anonymity.

This data collection took place between July to August 2013 following an exhaustive review of the research protocol by the Ethics Committee of the School of Health and Related Research (ScHARR), University of Sheffield, UK and the Human Research Ethics Committee, Institute of Public Health, Ile-Ife, Nigeria. No incentives were given to any participant.

\section{Measures}

Dual method use was the dependent variable, whereas the independent variables based potential correlates from literatures and constructs adopted from the ecological-based System theory $[63,64]$. This theory aggregates proximal and distal factors affecting health-related behaviours into multi-levels of influences: the microsystem (individual-level); the meso- and exosystems (interpersonal-level); and macrosystem (environmental-level) $[63,64]$. These variables are discussed below:

Dual-method: use was constructed based on the concepts of simultaneous use of male/female condom and non-barrier methods of contraception in a heterosexual relationship. Specifically, the primary outcome, DMC at last sex, was assessed from responses to two questions: (1) asking whether (yes/ no) respondents used any contraceptives at last sex, and (2) requiring participants to indicate, from two separate but identical contraceptives' lists, which methods were used during the last sexual intercourse by their partners and themselves. Individuals that answered 'yes' to the first question and who indicated usage of condoms along with a non-barrier contraception method were categorised as DMC users. Additionally, two questions assessed dual-method consistency over the last five sexual encounters [55]. Finally, participants were asked if they had ever-used DMC (yes/no) previously.

Individual-level measures: An adapted 6-item 5-point Likert-scale [67] assessed participant's agreement (1='strongly disagree' to $5=$ 'strongly agree') with various aspects of contraceptive use self-efficacy. In this line, some questions inquired about selfconfidence to have, use, or refuse sex without contraceptives (Cronbach Alpha $(\alpha)=0.70$ ( $\geq 0.7$ being adequate consistency). Second, perceived risk was assessed by two questions which asked participants their likelihood (on a five-point scale ranging from $1=$ 'extremely unlikely' to $5=$ 'extremely likely') of: (1) contracting STI/HIV, and (2) getting pregnant/impregnating their partner, if they did not use contraceptives over the next 12 months. Finally, single item measures assessed sexual risk-related behaviours like: age at first sex; number of sexual partners in past year; and previous history of unintended pregnancy or STIs.

Interpersonal-level: measures A composite indicator made of a 2-item, 5-point Likert-scale (inter-item correlation=0.25), was used to assess respondents' social normative belief. This scale assessed how participants' friends and families would react ( $1=$ 'very happy' to $5=$ 'very disappointed') if participants experienced an unintended pregnancy/impregnation now; and the extent to which their friends believed condoms were important ( $1=$ 'not important' to $5=$ 'extremely important') for sex with a new partner. Additionally, four questions assessed the nature of respondents' relationships with their main partners. A single question assessed relationship exclusivity and duration, whereas a 4 -item 5-point Likert-scale $(\alpha=0.88)$ assessed the quality of communication (1='very poor' to $5=$ 'very good') on STI/HIV and pregnancy preventions; contraceptives use; and partners' previous sexual history.

Environmental-level measure: A single question assessed the nature of participants' accommodation to ascertain the level of supervision in such households. Also, potential barriers to DMC, as derived from findings of other studies, were assessed through eleven questions (yes/no).

\section{Statistical analyses}

The collated data were inputted into SPSS 20.0 for descriptive and inferential analysis. Continuous data were appropriately categorised and negatively-worded statements were reversed scored. All scores were dichotomised using a median split and pairwise deletion was used to manage missing data. The unit of analysis was at the relationship level, hence male and female reports were analysed jointly.

To assess the correlates of DMC-at-last-sex (DMC-users), respondents that did not report DMC use (such as condom-only, hormonal-only and no-method users) were classified as non DMC-users and used as the referent. Since the outcome measure 
was dichotomous, multivariate logistic regressions were used. First, however, descriptive statistics were used for summarising measures. Chi-square $\left(X^{2}\right)$ tests assessed associations between potential socio-demographic covariates and DMC; predictors were deemed significant at the $90 \%$ level $(P<0.10)$. Subsequently, logistic regression was used to assess correlations, between DMC and each multi-level factor; this was expressed as crude odd ratios (OR) with significance at the $95 \%$ level $(P<0.05)$. Finally, in the multivariate analysis, the parsimonious significant bivariate correlates were entered into a logistic regression model, in one run, with the aim of assessing independent correlations expressed as adjusted odds ratio (AOR) $(P<0.05)$.

\section{Results}

\section{Participants characteristics}

The survey had a response rate of $95 \%$ with a total of 412 Nigerian undergraduate students from six faculties in the three selected universities (OAU, OUI, and FCM) participating in the study. These respondents comprised about equal numbers of male (196) and female (216) youths; their mean age was 22.3 years \pm 3.5 (SD), (range: 18 to 38 years); and about two-third (259) of them were OAU students. Of all respondents, only 259 youths reported current heterosexual activities, with a median age of 16 years at first encounter. All subsequent analysis is based on these sexually-active respondents and their socio-demographics are shown in Table 1. Approximately half (86) of them were aged 20-25 years, a third (87) were from natural Sciences faculty, and the majority (168) were in their final years. These youths were predominantly non-cohabiting singles (165), Christians (145), and Yoruba-speakers (183). Amongst all sub-groups, the figures were comparable across genders.

\section{Prevalence of dual-method contraception}

Out of these 259 sexually-active respondents, 82 (31.9\%) reported using only condoms, 12 (4.7\%) used only hormonal contraceptives, and 110 (42.8\%) used no contraceptive methods, at their last sexual encounters. On the other hand, $53(20.6 \%)$ respondents reported using DMC-at-last-sex, 76 (30.4\%) indicated that they had used DMC at some point in their lives, while only 14 (5.4\%) affirmed to being consistent users of DMC. The commonest DMC combinations were condom-OCP (60\%), condom-ECP (23\%) and condom-injectable (7.5\%); whereas, the condom-IUD was the least common combination (1.9\%). These rates were similar amongst both male and female respondents.

\section{Bivariate associations}

Bivariate chi-square and logistic regressions analyses were performed to uncover any associations and the strength of such associations between DMC use and other variables. Overall there were four times fewer people in the DMC-users group (53) compared with the non-DMC-users (204) group. The bivariate chisquare analyses testing for associations between DMC and sociodemographic variables showed no statistical relations at $P<0.10$ level and were therefore excluded from the logistic regression model (Table 1). On the other hand, in the bivariate logistic regression analyses, five variables were significantly associated with DMC (Table 2). Of the individual-level determinants, the odds of reporting DMC-at-last-sex were significantly increased for: those who commenced sexual intercourse at age 16 and above (OR=2.335; 95\% Cl, 1.036-5.261; $p=0.041$ ); youths with more than one sexual partner in the past year $(\mathrm{OR}=1.913 ; 95 \%$ $\mathrm{Cl}, 1.033-3.543 ; \mathrm{p}=0.039)$; those not currently seeking pregnancy (OR=2.412; 95\% Cl, 1.021-5.698; $\mathrm{p}=0.045)$; and respondents reporting previous history of unintended pregnancies (OR=2.220; $95 \% \mathrm{Cl}, 1.093-4.513 ; \mathrm{p}=0.027)$. Amongst the interpersonal factors, only supportive social norms emanating from social ties was a significant predictor of DMC-at-last-sex $(\mathrm{OR}=2.204 ; 95 \% \mathrm{Cl}$, 1.107-4.387; $p=0.025)$. However, having concurrent partners was tending towards significance $(p=0.053)$. The single environmental level factor was unrelated with respondent's DMC.

\section{Multivariate correlates}

To ascertain independent correlation and generate adjusted odd ratios, the five significant bivariate correlates were concurrently introduced into a multivariable logistic regression model. Of these variables, only two variables were significant the multivariate level (Table 3). These include: older age at first sex (AOR=3.081; $95 \% \mathrm{Cl},(1.053-9.013)$, which was the strongest predictor; and pregnancy intention $(A O R=2.929 ; 95 \% \mathrm{Cl}, 1.035-8.292 ; p<0.043)$. All other variables were not statistically significant. The correlates of consistent DMC were not assessed owing to limited cases for analysis.

\section{Barriers to dual-method contraception}

To assess barriers to dual-method, issues highlighted within findings of previously published literature were explored using both structured (9-item, yes/no questions) and open-ended questions. Results showed that a greater proportion of nonDMC-users were significantly more likely to report: difficulty with accessing contraceptives $\chi^{2}(1, N=246)=5.600, p=0.018$; and limited/infrequent counselling on contraception during their meetings with health professionals $\chi^{2}(1, N=246)=3.941, p=0.047$ (Table 4). All other investigated factors including affordability and quality of contraceptives, were not found to be statistically significant.

\section{Discussion}

The findings of this research amongst these respondents of sexually active Nigerian youths indicate that dual-method practice is uncommon both at last intercourse (20\%) and consistent use over time (5\%). Whilst, the DMC-at-last-sex rate was comparable to those of American college women [47], noncollege South Africans [45], and Kenyan youths [68], the rate of consistent use was markedly lower compared to other studies $[41,55]$. More worrisome was the discovery that over two-fifth of respondents used no protection at their last sex. These findings are consistent with reports of low national contraception rates and high contraceptive unmet needs in the country $[69,70]$.

In contrast with previous studies, we have not found an association between socio-demographic factors and DMC. For 
Table 1: Social demographic characteristics of respondents by gender and contraceptive method.*

\begin{tabular}{|c|c|c|c|c|c|c|c|}
\hline & \multirow{3}{*}{$\begin{array}{c}\text { Total } \\
\mathrm{N}=259 \\
n(\%)\end{array}$} & \multicolumn{3}{|c|}{ Gender } & \multicolumn{3}{|c|}{ Method Used } \\
\hline & & $\begin{array}{c}\text { Male } \\
\mathrm{N}=128(49.4)\end{array}$ & $\begin{array}{c}\text { Female } \\
\mathrm{N}=131(50.6)\end{array}$ & \multirow{2}{*}{$p$-Value } & $\begin{array}{l}\text { Dual-Method } \\
\mathrm{N}=53(20.8)\end{array}$ & $\begin{array}{l}\text { Non Dual-method } \\
\quad \mathrm{N}=204(79.2)\end{array}$ & \multirow{2}{*}{$p$-Value } \\
\hline & & $n(\%)$ & $n(\%)$ & & $n(\%)$ & $n(\%)$ & \\
\hline $\begin{array}{l}\text { University } \\
\text { OAU } \\
\text { OUI } \\
\text { FCM }\end{array}$ & $\begin{array}{l}161(62.4) \\
71(27.5) \\
26(10.1)\end{array}$ & $\begin{array}{l}64(39.8) \\
54(76.1) \\
10(38.5)\end{array}$ & $\begin{array}{l}97(60.2) \\
17(23.9) \\
16(61.5)\end{array}$ & 0.000 & $\begin{array}{l}35(22.2) \\
10(14.3) \\
7(25.9)\end{array}$ & $\begin{array}{l}123(77.8) \\
60(85.7) \\
20(74.1)\end{array}$ & 0.298 \\
\hline $\begin{array}{c}\text { Age Group(years) } \\
<20 \\
20-24 \\
\geq 25\end{array}$ & $\begin{array}{l}29(16.4) \\
86(48.6) \\
62(35.0)\end{array}$ & $\begin{array}{l}8(27.6) \\
36(41.9) \\
35(56.5)\end{array}$ & $\begin{array}{l}21(72.4) \\
50(58.1) \\
27(43.5)\end{array}$ & 0.028 & $\begin{array}{c}2(6.9) \\
20(23.5) \\
15(24.6)\end{array}$ & $\begin{array}{l}27(93.1) \\
65(76.5) \\
46(75.4)\end{array}$ & 0.119 \\
\hline $\begin{array}{c}\text { Study year } \\
100 \text { Level } \\
200 \text { Level } \\
300 \text { Level } \\
400 \text { Level/Final }\end{array}$ & $\begin{array}{c}17(6.6) \\
85(33.2) \\
25(9.8) \\
129(50.4)\end{array}$ & $\begin{array}{l}9(52.9) \\
36(42.4) \\
12(48.0) \\
70(54.3)\end{array}$ & $\begin{array}{l}8(47.1) \\
49(57.6) \\
13(52.0) \\
59(45.7)\end{array}$ & 0.390 & $\begin{array}{c}4(23.5) \\
16(18.8) \\
5(20.0) \\
27(21.4)\end{array}$ & $\begin{array}{l}13(76.5) \\
69(81.2) \\
20(80.0) \\
99(78.6)\end{array}$ & 0.958 \\
\hline $\begin{array}{l}\text { Faculty of Study } \\
\text { Administration } \\
\text { Art } \\
\text { Health Sciences } \\
\text { Law } \\
\text { Sciences } \\
\text { Social Sciences }\end{array}$ & $\begin{array}{l}47(18.3) \\
32(12.5) \\
19(7.4) \\
43(16.7) \\
87(33.9) \\
29(11.3)\end{array}$ & $\begin{array}{l}30(63.8) \\
13(40.6) \\
8(42.1) \\
19(44.2) \\
37(42.5) \\
21(72.4)\end{array}$ & $\begin{array}{l}17(36.2) \\
19(59.4) \\
11(57.9) \\
24(55.8) \\
50(57.5) \\
8(27.6)\end{array}$ & 0.019 & $\begin{array}{c}9(19.1) \\
6(18.8) \\
2(11.1) \\
15(36.6) \\
15(17.4) \\
6(20.0)\end{array}$ & $\begin{array}{l}38(80.9) \\
26(81.2) \\
16(88.9) \\
26(63.4) \\
71(82.6) \\
24(80.0)\end{array}$ & 0.158 \\
\hline $\begin{array}{c}\text { Ethnicity } \\
\text { Hausa } \\
\text { Igbo } \\
\text { Yoruba } \\
\text { Minority groups }\end{array}$ & $\begin{array}{c}8(3.2) \\
51(20.2) \\
183(72.3) \\
11(4.3)\end{array}$ & $\begin{array}{l}3(37.5) \\
30(58.8) \\
90(49.2) \\
5(45.5)\end{array}$ & $\begin{array}{l}5(62.5) \\
21(41.2) \\
93(50.8) \\
6(54.5)\end{array}$ & 0.533 & $\begin{array}{c}2(25.0) \\
12(23.5) \\
34(18.9) \\
3(27.3)\end{array}$ & $\begin{array}{c}6(75.0) \\
39(76.5) \\
146(81.1) \\
8(72.7)\end{array}$ & 0.805 \\
\hline $\begin{array}{l}\text { Marital Status } \\
\text { Single } \\
\text { Cohabiting } \\
\text { Married } \\
\text { Divorced/Separated }\end{array}$ & $\begin{array}{c}165(67.3) \\
39(15.9) \\
25(10.2) \\
16(6.5)\end{array}$ & $\begin{array}{l}94(57.0) \\
18(46.2) \\
5(20.0) \\
4(25.0)\end{array}$ & $\begin{array}{l}71(43.0) \\
21(53.8) \\
20(80.0) \\
12(75.0)\end{array}$ & 0.001 & $\begin{array}{l}30(18.3) \\
11(28.2) \\
4(17.4) \\
6(37.5)\end{array}$ & $\begin{array}{l}134(81.7) \\
28(71.8) \\
19(82.6) \\
10(62.5)\end{array}$ & 0.192 \\
\hline $\begin{array}{l}\text { Religious Affiliation } \\
\text { Christian } \\
\text { Catholic } \\
\text { Muslim } \\
\text { Traditional/Atheist/Others }\end{array}$ & $\begin{array}{l}145(58.0) \\
33(13.2) \\
36(14.4) \\
36(14.4)\end{array}$ & $\begin{array}{l}84(57.9) \\
16(48.5) \\
14(38.9) \\
14(38.9)\end{array}$ & $\begin{array}{l}61(42.1) \\
17(51.5) \\
22(61.1) \\
22(61.1)\end{array}$ & 0.069 & $\begin{array}{c}26(18.3) \\
8(23.5) \\
10(27.8) \\
4(11.4)\end{array}$ & $\begin{array}{l}116(81.7) \\
26(76.50 \\
26(72.2) \\
31(88.6)\end{array}$ & 0.319 \\
\hline
\end{tabular}

Notes:*-Figures may not add up to 259 , owing to missing cases. Chi-square tests $\left(\mathrm{X}^{2}\right)$. Significant level at $p$-Value $<0.05$. All significant values are in bold.

instance, younger age has been extensively linked with increased DMC use $[43,44,46,71,72]$; however, such link was not found here. Though a critical scrutiny reveals a disproportionately small number of under 20-year-olds among respondents, the homogeneity of a university sample might also be a contributing factor; particularly since higher education has also been strongly linked with DMC $[73,74]$.

On the other hand, the strongest independent predictor of DMC use among these youths was age at first intercourse; this was similar to the findings reported in a study of 14-22-year-olds [71]. In our study, those initiating coitus at age 16 years and above were three times more likely to report DMC-at-last-sex than earlier initiators. This could be linked with associated lower condom use and higher risk taking of earlier initiators who may see the need for little or no contraception [75]. Alternatively, older initiators may be wiser and capable of making informed safer-sex decisions.
Another significant multivariate correlate was family formation intentions. Similar to other studies $[52,76]$, college youths that were currently non-desirous of children had higher odds of reporting DMC. This was unsurprising, since dual-method protects optimally against unintended pregnancies [33]. Moreover, the need to avoid unintended conceptions is important for these predominantly unmarried Nigerians because of the: restrictive abortion laws in the country, poor health services, and adverse socio-economic implications of such pregnancies $[12,77]$. Similarly, it was not strange that a history of previous unintended conception(s) was also a strong DMC correlate amongst these youths, despite opposite findings in other samples $[34,76]$. However, this correlation was only at the bivariate level.

Having multiple sexual partners in the past year was also a bivariate predictor of DMC. Consistent with other studies $[53,54]$, individuals reporting multiple partners in the past year, were almost twice as likely to report dual-method use than 
Table 2: Bivariate associations between independent variables and dual-method and non-dual method users.*

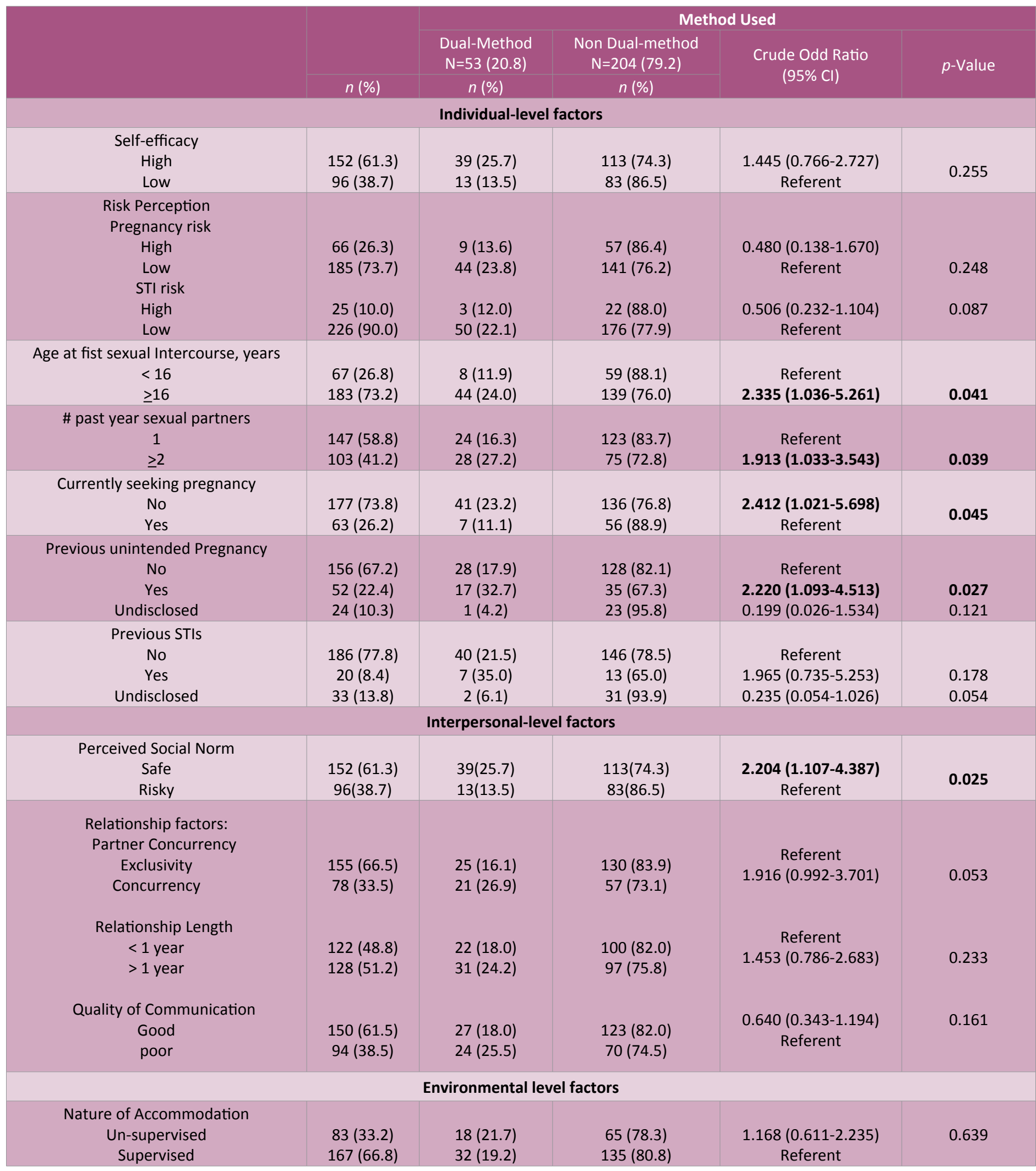

Notes: *- Figures may not add up to 257 , owing to missing cases. Significant level at $p$-Value $<0.05$. All significant values are in bold.

those in one-to-one relationships. This implies that these youths understand the risks of multiplicity. Likewise, respondents who affirmed to being subject to expectations of normative decorum from family and close peers, concerning sex and pregnancy, were

more likely to use DMC: this finding is confirmed by other studies $[52,78]$.

Unlike the individual and interpersonal level factors, however, the sole environmental-level factor -quality of accommodation- 
Table 3: Multivariate correlates of dual-method compared with No-dual method use (referent)*.

\begin{tabular}{|c|c|c|}
\hline & Dual-Method against Non-dual method (referent) & \\
\hline & Adjusted Odd Ratio $(95 \% \mathrm{Cl})$ & $p$-Value \\
\hline \multicolumn{3}{|c|}{ Individual-level factors } \\
\hline $\begin{array}{l}\text { Age at fist sexual Intercourse, years } \\
\qquad \begin{aligned}<16 \\
\geq 16\end{aligned}\end{array}$ & $\begin{array}{c}\text { Referent } \\
3.081(\mathbf{1 . 0 5 3 - 9 . 0 1 3 )}\end{array}$ & 0.040 \\
\hline $\begin{array}{c}\text { \# past year sexual partners } \\
1 \\
\geq 2\end{array}$ & $\begin{array}{c}\text { Referent } \\
1.684(0.720-3.940)\end{array}$ & 0.230 \\
\hline $\begin{array}{l}\text { Currently seeking pregnancy } \\
\text { No } \\
\text { Yes }\end{array}$ & $\begin{array}{c}2.929(1.035-8.292) \\
\text { Referent }\end{array}$ & 0.043 \\
\hline $\begin{array}{c}\text { Previous unintended Pregnancy } \\
\text { No } \\
\text { Yes } \\
\text { Undisclosed }\end{array}$ & $\begin{array}{c}\text { Referent } \\
1.746(0.667-4.572) \\
0.233(0.029-1.855)\end{array}$ & $\begin{array}{l}0.257 \\
0.169\end{array}$ \\
\hline \multicolumn{3}{|c|}{ Interpersonal-level factors } \\
\hline $\begin{array}{l}\text { Social Norm } \\
\text { Safer } \\
\text { Risky }\end{array}$ & $\begin{array}{c}1.462(0.668-3.202) \\
\text { Referent }\end{array}$ & 0.342 \\
\hline
\end{tabular}

Notes: *Significant level at $p$-Value $<0.05$ and confidence intervals not crossing 1.00. All significant values are in bold.

Table 4: Barriers of dual-method use compared with non-dual method use.

\begin{tabular}{|c|c|c|c|c|}
\hline & \multirow[b]{2}{*}{$\begin{array}{l}\text { Total } \\
\mathrm{N}=259\end{array}$} & \multicolumn{2}{|c|}{ Contraception used at last sex } & \multirow[b]{2}{*}{$p$-Value } \\
\hline & & $\begin{array}{l}\text { Dual-Method } \\
\mathrm{N}=53(20.8)\end{array}$ & $\begin{array}{l}\text { Non Dual-method } \\
\quad \mathrm{N}=204(79.2)\end{array}$ & \\
\hline & $n(\%)$ & $n(\%)$ & $n(\%)$ & \\
\hline $\begin{array}{c}\text { Accessibility of Contraception (CT) } \\
\text { Easy } \\
\text { Difficult }\end{array}$ & $\begin{array}{l}211(85.8) \\
35(14.2)\end{array}$ & $\begin{array}{c}49(96.1) \\
2(3.9)\end{array}$ & $\begin{array}{c}162(83.1) \\
33(16.9)\end{array}$ & 0.018 \\
\hline $\begin{array}{c}\text { Health Personnel counsels on CT } \\
\text { Often } \\
\text { Infrequent }\end{array}$ & $\begin{array}{l}175(71.1) \\
71(28.9)\end{array}$ & $\begin{array}{c}42(82.4) \\
9(17.6)\end{array}$ & $\begin{array}{c}133(68.2) \\
62(31.8)\end{array}$ & 0.047 \\
\hline $\begin{array}{c}\text { Proximity of CT Purchase Points } \\
\text { Proximal } \\
\text { Distant }\end{array}$ & $\begin{array}{c}185(75.5) \\
60(24.5)\end{array}$ & $\begin{array}{l}40(78.4) \\
11(21.6)\end{array}$ & $\begin{array}{c}145(74.7) \\
49(25.3)\end{array}$ & 0.586 \\
\hline $\begin{array}{c}\text { Satisfaction with CT services } \\
\text { Satisfied } \\
\text { Unsatisfied }\end{array}$ & $\begin{array}{l}171(70.1) \\
73(29.9)\end{array}$ & $\begin{array}{l}34(66.7) \\
17(33.3)\end{array}$ & $\begin{array}{c}137(71.0) \\
56(29.0)\end{array}$ & 0.549 \\
\hline $\begin{array}{c}\text { Satisfaction with available CT qualities } \\
\text { Satisfied } \\
\text { Unsatisfied }\end{array}$ & $\begin{array}{l}132(53.7) \\
114(46.3)\end{array}$ & $\begin{array}{l}25(48.1) \\
27(51.9)\end{array}$ & $\begin{array}{l}107(55.2) \\
87(44.8)\end{array}$ & 0.363 \\
\hline $\begin{array}{c}\text { Affordability of CT } \\
\text { Affordable } \\
\text { Unaffordable }\end{array}$ & $\begin{array}{l}141(58.0) \\
102(42.0)\end{array}$ & $\begin{array}{l}28(54.9) \\
23(45.1)\end{array}$ & $\begin{array}{c}79(41.1) \\
113(58.9)\end{array}$ & 0.611 \\
\hline $\begin{array}{c}\text { Embarrassment with CT Procurement } \\
\text { Disturbed } \\
\text { undisturbed }\end{array}$ & $\begin{array}{l}117(47.6) \\
129(52.4)\end{array}$ & $\begin{array}{l}22(42.3) \\
30(57.7)\end{array}$ & $\begin{array}{l}95(49.0) \\
99(51.0)\end{array}$ & 0.393 \\
\hline $\begin{array}{c}\text { Family support for CT use } \\
\text { Supportive } \\
\text { Antagonistic }\end{array}$ & $\begin{array}{l}113(46.3) \\
131(53.7)\end{array}$ & $\begin{array}{l}25(49.0) \\
26(51.0)\end{array}$ & $\begin{array}{c}88(45.6) \\
105(54.4)\end{array}$ & 0.663 \\
\hline $\begin{array}{c}\text { Religious Prohibitions of CT use } \\
\text { None } \\
\text { worrisome }\end{array}$ & $\begin{array}{l}137(56.1) \\
107(43.9)\end{array}$ & $\begin{array}{l}32(62.7) \\
19(37.3\end{array}$ & $\begin{array}{c}105(54.4) \\
88(45.6)\end{array}$ & 0.286 \\
\hline
\end{tabular}

Notes: *Figures may not add up to 259 , owing to missing cases. Significant level at $p$-Value $<0.05$. All significant values are in bold. 
was unrelated to DMC. Although, urban residency [51] and neighbourhood cohesion [76] have been linked to dual-method, others have found no association between DMC and quality of the neighbourhood [78]. These mixed results cannot be explained and further research is warranted.

That said, amongst non-DMC-user students, poor accessibility of contraceptives and inadequate health personnel communication were the significant DMC barriers. Problems with contraceptive accessibility in this particular setting are pronounced [70,79]; it is a problem that also persists in developed countries [72]. Also, communication on contraceptive use, particularly from significant individuals (like health workers and notable community members), has been linked with better compliance [43]. Lack of counselling by health personnel was also an identified barrier in studies conducted in other countries too $[80,81]$. This arguably demonstrates the hugely important missed opportunity for health personnel in terms of promoting young people's sexual and reproductive health. Also, it was interesting to find that the cost and qualities of contraceptives were not deterrents to youths' DMC-use; perhaps, infrequent contraceptive use or the national contraceptive subsidy could account for this finding.

To the best of our knowledge, this is the first study on DMC in this setting and as such can serve as a reference for the determinants and barriers of DMC in Nigeria. However, a snapshot's view of DMC-at-last-sex might have grossly under-represented DMC practices amongst the respondents; since a faithful user missing this last-episode would have been classified as a non-user. We have also assessed consistency of use to provide more insight in this regard. Another study limitation is that the study focuses on specific population groups (university students) and these findings can only be generalised to youths coming from such institutions, with similar characteristics. It may not apply to adolescents, out-of-school and other disadvantaged youths, and the wider Nigerian youth population.

Thirdly, whilst it was worthwhile to adapt an ecological perspective for this study; the structural/environmental factors were only probed minimally. Perhaps, the role of media, sociocultural influences, and health-providers views could have also been elucidated. However, the time scope of this project and the resources available did limit such a broad level of investigation. Finally, self-reports are prone to social desirability bias, which may cause both under-reporting of risky behaviours and overreporting of DMC use. Also, males might have under-reported dual-method because they could have been unaware of their partners' contraceptive use. This is not just specific to this study but rather a commonality to all surveys of this kind [82].

\section{Implications of the Study}

Our study presents findings on the level of use of DMC in a developing country context and identifies factors that are associated with observed trends in use of DMC. In this regard, the observed levels of use are very low in a context that bears significant burdens of the dual problems of unintended pregnancies and HIV/STIs. The factors that were found to be significantly associations with use of DMC provide further insights into the critical cognitive and social factors at play, which can in turn be targeted by reproductive health policies that aim to bolster the use of DMC in the setting. Such policies need to adopt a multi-level, multi-pronged approach. First, contraceptive supplies need to be made accessible to the youth through youth-friendly centres. Second, counselling of young people on reproductive health matters, including DMC, needs to be streamlined into routine health services provision, so as to minimise missed opportunities in this regard. Such services need to include birth control options including DMC, DP and behavioural modification.

Also, some indicators of sexual behaviour and practice have been associated with observed trends in DMC use, such as, age of first sex. This further strengthens calls for comprehensive community based sexual health education for adolescents and openness regarding sexuality and sexual health within families. Further studies that also include qualitative analysis of young people's choices in these settings would provide more comprehensive and context specific insights into the factors at play. In this regard, other stakeholder's views such as health workers, counsellors and social workers could be elicited. Finally, as an area that has not been extensively targeted by interventions, there is need for action researches that would test innovative interventions aimed at bolstering usage within community settings.

\section{Acknowledgments}

We gratefully thank all study participants and acknowledge the research inputs of Pharm. Dapo Jegede and Misters Tobi llesanmi and Dennis Oketunbi.

\section{Author Contributions}

OB, PS PW conceived and designed the experiments; OB performed the experiments; OB PS PW and HBT informed the study's analytic strategy; $O B$ implemented and managed the study; OB and PW analyzed the data; OB wrote the paper; PS, PW and HBT reviewed numerous drafts of the article; PS and PW supervised the study. 


\section{References}

1 World Health Organisation (2013) Sexually transmitted infections (STIS).

2 World Health Organisation (2012) Global incidence and prevalence of selected curable sexually transmitted infections 2008: 1-21.

3 Joint United Nations Actions on HIV/AIDS (UNAIDS) (2012) Global report: UNAIDS Report on the global AIDS epidemic 2012.

4 Guttmacher Institute (1999) Sharing responsibility: women, society and abortion worldwide. New York.

5 Gerbase AC, Rowley JT, Mertens TE (1998) Global epidemiology of sexually transmitted diseases. Lancet 351: S2-S4.

6 Klima C (1998) Unintended pregnancy Consequences and solutions for a worldwide problem. J Nurse Midwifery 43: 483-491.

7 Glasier A, Gülmezoglu AM, Schmid GP, Moreno CG, Van Look PFA (2006) Sexual and reproductive health: a matter of life and death. Lancet 368: 1595-1607.

8 UNFPA (2003) UNFPA: preventing HIV/AIDS among adolescents through integrated communication programming.: 1-117.

9 United Nations Department of Economic and Social Affairs Population Division (2011) World population prospects: the 2010 revision, highlights and advance tables. New York.

10 Okonofua $F$ (1997) Preventing unsafe abortion in Nigeria. Afr J Reprod Health 1: 25-36.

11 Henshaw SK, Singh S, Oye-Adeniran BA, Adewole IF, Iwere N, et al. (1998) The Incidence of induced abortion in Nigeria. Int Fam Plan Perspect 24: 156-164.

12 Okonofua FE, Hammed A, Nzeribe E, Saidu B, Abass T, et al. (2009) Perceptions of policymakers in Nigeria toward unsafe abortion and maternal mortality. Int Perspect Reprod Heal 35: 194-202.

13 Nigeria National Agency for the Control of AIDS (NACA) (2012) Federal Republic of Nigeria global AIDS response (GARPR): country progress report 2012. Abuja.

14 Joint United Nations Actions on HIV/AIDS (UNAIDS) (2012) UNAIDS: Nigeria-HIV and AIDS estimates (2011). UNAIDS Niger.

15 Ikimalo J, Obunge OK, Babatunde S, Ikokwu-Wonodi C, Briggs ND, et al. (1999) Sexually transmitted infections among Nigerian adolescent schoolgirls. Sex Transm Infect 75: 121.

16 Brabin L, Kemp J, Dollimore N, Obunge O, Ikimalo J, et al. (1995) Reproductive tract infections and abortion among adolescent girls in rural Nigeria. Lancet 345: 300-304.

17 Oyelese A, Onipede A, Aboderin A, Adedosu A, Onayemi O (2004) Sexually transmitted infections in Obafemi Awolowo University Teaching Hospital, Ile-Ife, Nigeria: A decade of clinic experience. African J Clin Exp Microbiol 6: 64-68.

18 Fotso JC, Ajayi JO, Idoko EE, Speizer I, Fasiku DA, et al. (2011) Family Planning and reproductive health in urban Nigeria: Levels, trends and differentials. Chapel Hill, NC.

19 Askew I, Mensch B, Adewuyi A (1994) Indicators for measuring the quality of family planning services in Nigeria. Stud Fam Plann 25 268-283.

20 Hindin MJ, Fatusi AO (2009) Adolescent Sexual and Reproductive Health in Developing Countries: An Overview of Trends and Interventions. Int Perspect Sex Reprod Health 35: 58-62.

21 IPPF, UNFPA, WHO, UNAIDS, GNP+, et al. (2008) Rapid assessment tool for sexual \& reproductive health and HIV linkages: a Generic Guide. Mexico City.
22 Berer M (1997) Dual Protection: making Sex safer for women. In: Ravindran TK., Berer M, Cottingham J, editors. Reproductive Health Matters. London, Netherlands: Reproductive health matters for WHO, Vol. 14. pp. 109-121

23 Woodsong C, Koo HP (1999) Two good reasons: women's and men's perspectives on dual contraceptive use. Soc Sci Med 49: 567-580.

24 Berer M (2006) Dual protection: more needed than practised or understood. Reprod Health Matters 14: 162-170.

25 Murray CC, Hatfield-Timajchy K, Kraft JM, Bergdall AR, Habel MA, et al. (2013) In their own words: romantic relationships and the sexual health of young African American women. Public Health Rep 128 Suppl : 33-42.

26 Berer M (2006) Dual protection: more needed than practised or understood. Reprod Health Matters 14: 162-170.

27 Cates W, Steiner M (2002) Dual protection against unintended pregnancy and sexually transmitted infections: what is the best contraceptive approach? Sex Transm Dis 29: 168-174.

28 Adeokun L, Mantell JE, Weiss E, Delano GE, Jagha T, et al. (20002) Promoting dual protection in family planning clinics in Ibadan, Nigeria. Int Fam Plan Perspect 28: 87-95.

29 Kleinschmidt I, Maggwa BN, Smit J, Beksinska ME, Rees H (2003) Dual protection in sexually active women. S Afr Med J 93: 854-857.

30 O'Leary A (2011) Are dual-method messages undermining STI/HIV prevention?. Infect Dis Obstet Gynecol, 2011

31 Gallo MF, Grimes DA, Lopez LM, Schulz KF (2006) Non-latex versus latex male condoms for contraception. Cochrane Database Syst Rev 1: 103

32 Trussel J (2007) Contraceptive efficacy. In: Hatcher RA, Trussell J, Nelson AL, Cates W, Stewart FH, et al., editors. Contraceptive technology. New York: Ardent Media,Inc. pp. 297-316.

33 Cates W, Stone KM (1992) Family planning, sexually transmitted diseases and contraceptive choice: a literature update--Part II. Fam Plann Perspect 24: 122-128.

34 Svare EI, Kjaer SK, Poll P, Bock JE (1997) Determinants for contraceptive use in young, single, Danish women from the general population. Contraception 55: 287-294.

35 Gregson J, Kirkman R (1999) Double Dutch: looking at the usage of combined pill plus condom in girls under 25. Eur J Contracept Reprod Health Care 4: 45-48.

36 Williams RL, Fortenberry JD (2013) Dual use of long-acting reversible contraceptives and condoms among adolescents. J Adolesc Health 52: S29-34.

37 Pazol K, Kramer MR, Hogue CJ (2010) Condoms for dual protection: patterns of use with highly effective contraceptive methods. Public Health Rep 125: 208-217.

38 Cushman LF, Romero D, Kalmuss D, Davidson AR, Heartwell S, et al (1998) Condom use among women choosing long-term hormonal contraception. Fam Plann Perspect 30: 240-243.

39 Ott MA, Adler NE, Millstein SG, Tschann JM, Ellen JM (2002) The trade-off between hormonal contraceptives and condoms among adolescents. Perspect Sex Reprod Health 34: 6-14.

40 Wilson TE, Koenig LJ, Walter E, Fernandez I, Ethier K, et al. (2003) Dual contraceptive method use for pregnancy and disease prevention among HIV-infected and HIV-uninfected women: the importance of an event-level focus for promoting safer sexual behaviors. Sex Transm Dis 30: 809-812. 
41 Sangi-Haghpeykar H, Posner SF, Poindexter AN. (2005) Consistency of condom use among low-income hormonal contraceptive users. Perspect Sex Reprod Health 37: 184-191.

42 Higgins JA, Cooper AD (2012) Dual use of condoms and contraceptives in the USA. Sex Health 9: 73-80.

43 Morroni C, Tibazarwa K, Myer L (2006) Combined condom and contraceptive use among South African women. S Afr Med J 96: 620622.

44 Parr N, Siedlecky S (2007) Use of "dual protection" and other combinations of contraceptive methods in Australia. Aust N Z J Public Health 31: 567-570.

45 Myer L, Morroni C, Matthews C, Little F (2002) Dual Method Use in South Africa. Int Fam Plan Perspect 28: 119-121.

46 Raine TR, Foster-Rosales A, Upadhyay UD, Boyer CB, Brown BA, et al. (2011) One-year contraceptive continuation and pregnancy in adolescent girls and women initiating hormonal contraceptives. Obstet Gynecol 117: 363-371.

47 Poppen PJ, Reisen CA (1999) Women's use of dual methods of sexual self-protection. Women Health 30: 53-66.

48 Santelli JS, Davis M, Celentano DD, Crump AD, Burwell LG (1995) Combined use of condoms with other contraceptive methods among inner-city Baltimore women. Fam Plann Perspect 27: 74-78.

49 Sieving RE, Bearinger LH, Resnick MD, Pettingell S, Skay C (2007) Adolescent dual method use: relevant attitudes, normative beliefs and self-efficacy. J Adolesc Health 40: 215-222.

50 Lindberg LD, Ku L, Sonenstein FL (1998) Adolescent males' combined use of condoms with partners' use of female contraceptive methods. Matern Child Health J 2: 201-209.

51 MacPhail C, Pettifor A, Pascoe S, Rees H (2007) Predictors of dual method use for pregnancy and HIV prevention among adolescent South African women. Contraception 75: 383-389.

52 Kraft JM, Galavotti C, Carter M, Jamieson DJ, Busang L, et al. (2009) Use of dual protection in Botswana. Stud Fam Plann 40: 319-328.

53 Harvey SM, Henderson JT, Branch MR (2004) Protecting against both pregnancy and disease: predictors of dual method use among a sample of women. Women Health 39: 25-43.

54 Morroni C, Smit J, McFadyen L, Mqhayt M, Beksinska M (2003) Dua protection against sexually transmitted infections and pregnancy in South Africa. Afr J Reprod Health 7: 13-19.

55 Crosby RA, DiClemente RJ, Wingood GM, Sionean C, Cobb BK, et al. (2001) Correlates of using dual methods for sexually transmitted diseases and pregnancy prevention among high-risk africanamerican female teens. J Adolesc Heal 28: 410-414.

56 Pack RP, Li X, Stanton BF, Cottrell LA (2011) Psychosocial Correlates of Dual Methods for Contraception and STI Protection in Urban Adolescents. ISRN Obstet Gynecol, 2011

57 OAU (2012) Obafemi Awolowo University, Ile-Ife.

58 Oduduwa University (2013) Oduduwa University: About the University.

59 Foreign link (2013) Foreign Links Campus: faculties and department.

60 Niang L, Winn T, Rusli BN (2006) Practical issues in Calculating the sample size for prevalence studies. Arch Orofac Sci 1: 9-14.

61 Fox N, Hunn A, Mathers N (2007) Sampling and sample size calculation. Nottingham.

62 Frankfort-Nachmias C, Nachmias D (1992) Resarch methods in the social sciences. 4th ed. London: Edward Arnold.
63 Bronfenbrenner U (1979) The ecology of human development: experiments by nature and design. Cambridge, MA: Harvard University Press.

64 DiClemente RJ, Salazar LF, Crosby RA (2007) A review of STD/HIV preventive interventions for adolescents: sustaining effects using an ecological approach. J Pediatr Psychol 32: 888-906.

65 Davis CM, Yarber WL, Bauserman R, Schreer GE, Davis SL (2005) Handbook of Sexuality-Related Measures. SAGE Publications, Inc.

66 Readabilityformula (2013) Readability formulas tools: calculator.

67 Levinson RA (1998) Contraceptive self-efficacy scale. In: Davis CM, Yarber WL, Bauserman R, Schreer G, Davis LS, editors. Handbook of sexuality-related measures. New Delhi: Sage Publications. pp. 166-168.

68 Kuyoh M, Spruyt A, Johnson L. (1999) Dual method use among family planning clients in Kenya.

69 Nigeria National Population Commission(NPC), ICF Macro (2009) Nigeria Demographic and Health Survey (NDHS) 2008. Abuja, Nigeria.

70 Monjok E, Smesny A, Ekabua JE, Essien JE (2010) Contraceptive practices in Nigeria: Literature review and recommendation for future policy decisions. Open Access J Contracept 1: 9-22.

71 Santelli JS, Warren CW, Lowry R, Sogolow E, Collins J, et al. (1997) The use of condoms with other contraceptive methods among young men and women. Fam Plann Perspect 29: 261-267.

72 Eisenberg DL, Allsworth JE, Zhao Q, Peipert JF (2012) Correlates of dual-method contraceptive use: an analysis of the National Survey Of Family Growth (2006-2008). Infect Dis Obstet Gynecol, 2012

73 Anderson JE, Santelli J, Gilbert BC (2003) Adolescent dual use of condoms and hormonal contraception: trends and correlates 19912001. Sex Transm Dis 30: 719-722.

74 Peipert JF, Zhao Q, Meints L, Peipert BJ, Redding CA, et al. (2011) Adherence to dual-method contraceptive use. Contraception 84: 252-258.

75 Greenberg J, Magder L, Aral S (1992) Age at first coitus. A marker for risky sexual behavior in women. Sex Transm Dis 19: 331-334.

76 Lang DL, Sales JM, Salazar LF, DiClemente RJ, Crosby RA, et al. (2011) Determinants of multimethod contraceptive use in a sample of adolescent women diagnosed with psychological disorders. Infect Dis Obstet Gynecol, 2011.

77 Grimes DA, Benson J, Singh S, Romero M, Ganatra B, et al. (2006) Unsafe abortion: the preventable pandemic. Lancet 368: 1908-1919.

78 Sales JM, Latham TP, Diclemente RJ, Rose E (2010) Differences between dual-method and non-dual-method protection use in a sample of young African American women residing in the Southeastern United States. Arch Pediatr Adolesc Med 164: 1125-1131.

79 Oye-Adeniran BA, Adewole IF, Umoh A V, Oladokun A, Gbadegesin $A$, et al. (2005) Sources of contraceptive commodities for users in Nigeria. PLoS Med 2: 306.

80 Akintade OL, Pengpid S, Peltzer K (2011) Awareness and use of and barriers to family planning services among female university students in Lesotho. S Afr J Obstet Gynaecol 17: 72-78.

81 Chakrapani V, Kershaw T, Shunmugam M, Newman PA, Cornman $\mathrm{DH}$, et al. (2011) Prevalence of and barriers to dual-contraceptive methods use among married men and women living with HIV in India. Infect Dis Obstet Gynecol 2011: 376-432.

82 Ezeh AC, Mboup G (1997) Estimates and explanations of gender differentials in contraceptive prevalence rates. Stud Fam Plann 28: 104-121. 